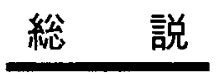

\title{
堲・ペプチド・核酸系双頭型脂質の構造形成
}

\author{
清水 敏美 \\ 物質工学工業技術研究所有機材料部 \\ ポリマーオブジェクトグループ \\ (干305-8565 茨城県つくば市東 1-1)
}

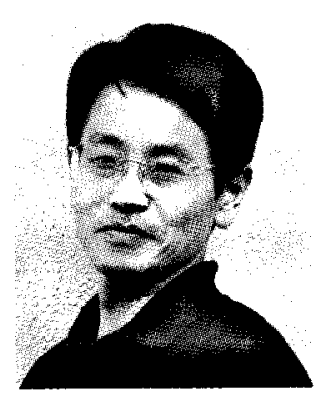

\section{Formation of High-Axial-Ratio Microstructures from Sugar-, Peptide-, and Nucleobase-based Bolaamphiphiles}

\author{
Toshimi Shimizu \\ Polymer Objects Group, Department of Organic Materials \\ National Institute of Materials and Chemical Research \\ (1-1 Higashi, Tsukuba-shi, Ibaraki-ken 305-8565)
}

\begin{abstract}
A variety of bola-form amphiphiles (bolaamphiphiles), in which sugar, peptide, or nucleobase moieties are connected to both ends of a hydrocarbon spacer, were synthesized. These compounds self-assembled in aqueous solution to form thermally stable, nanometer-scale highaxial-ratio microstructures (HARMs), such as helical fibers, tubular fibers, and double-helical ropes. Size distribution of the structures was essentially the same as that of self-assembled fibrous structures like collagen fibers, flagella, and actin fibers and morphology was found to strongly depend on chain length and even-odd carbon number of used oligomethylene spacers. Molecular arrangement and hydrogen bond networks within HARMs were investigated by FT-IR, XRD, and AFM. Interlayer and intralayer interactions of the monolayers were noted to be major determinants of fiber morphology. HARMs are constructed hierarchically in a manner similar to biological structures.
\end{abstract}

Key words : bolaamphiphile, microtube, helical fibers, self-assembly, hydrogen bonds

\section{1 はじめに}

生体系の構造的な特徵は, 数多くの異なった原子オ一 ターのサイズ次元を有する構造単位が階層的な組織化を 起こし，しかも，それが自発的に形成することである1。 生体系特有のエネルギーを高勃率に利用する機能や特性 の発現はまさに，その自己組織化構造に由来する。これ に対し，既存の有機合成化学的な手法では複雑な巨大分 子の合成や高分子構造の制御は，高々，数 $\mathrm{nm}$ 以下の籁 囲にとどまっている。もし，生体系の構造構築原理を最 先端の材料設計に生かせたら, 興味ある構造や機能の発 現が期待できる゙)。

我々は，多重の水素結合形成が可能な楉，ペプチド， 核酸塩基などを親水部とする双頭型脂質を系統的に合成 し，水媒体中での自己集合挙動と得られた構造体の特性 を詳紐に検討してきた ${ }^{33}$ 。その結果，従来報告例が全く
なかったマイクロチューブなど,ナノメータスケールの 多様な径サイズをもち，高い軸比に特徴づけられる極微 小構造体 (HARM $=$ High-Axial-Ratio Microstructures) が，簡単な構造をもつ合成脂質から自発的に構筑できる ことを示した。また，これら HARM が従来のコロイド 化学で知られるミセルやべシクルなどの球状分子集合体 とも,有機の固体結晶とも異なり,短距離の規則性をもっ て階層的に高次搼造形成を起こすことを特徵とする新し い固相群であることも見いだした。

\section{2 水秦結合と分子集合形態}

親水部と疎水部から成る両親媒性化合物の分子内に水 素結合性官能基を一つ，二つと導入していった場合の親 水性頭部の配列や集合形態に与える影響を Fig. 1 にま とめた。両親媒性化合物は水中で自己集合し，一般的に は球状べシクルやミセル構造といったナノメータスケー 


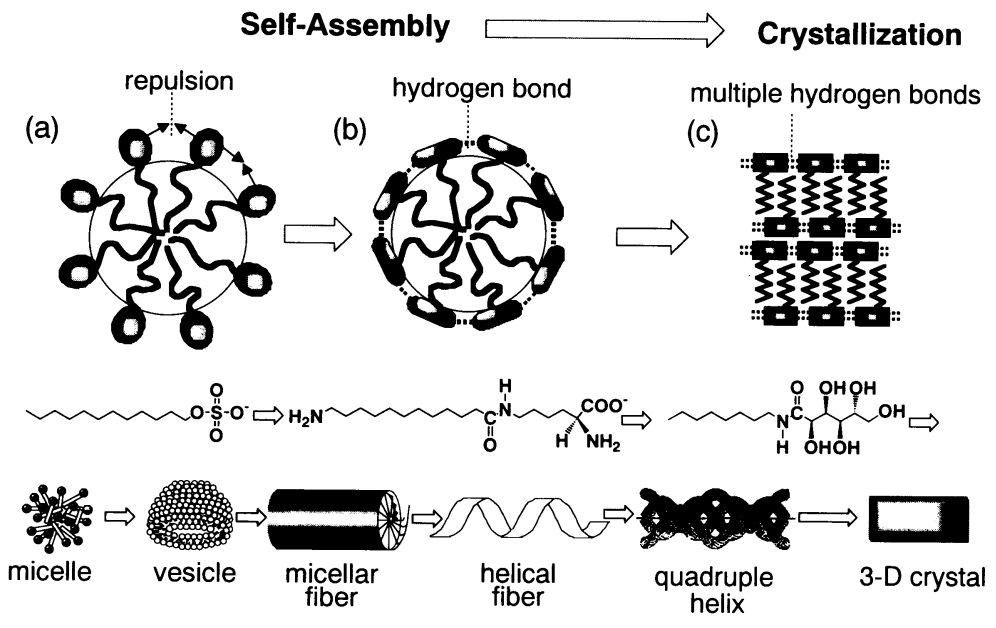

Fig. 1 The Effect of Hydrogen Bonding on Headgroup Arrangement in Self-assembled Structures.

ルの閉じた形態を持つ集合体を与える4)。この時，疎水 部間に働く疎水性効果は分子同士の会合を引き起こし膜 構造を安定化させるが，表面での水和斥力や立体的反発 は，よりサイズの大きな三次元結晶への成長を妨げる

(Fig. $1($ a $))^{5)}$ 。これら集合体表面の親水性頭部の配列 は流動的である。次に，分子中に水素結合性官能基を導 入し，例えば二分子膜界面近傍で水素結合鎖（あるいは ネットワーク）を形成させると，水和が抑えられ集合体 表面が固体的になる (Fig. 1 (b) ) ${ }^{6)}$ 。この観点から， Fuhrhop らはミセルやベシクルから種々の繊維状会合体 への形態変化を詳細に検討している7)。

\section{3 双頭型脂質}

それでは，水素結合を集合体中の膜界面の近傍で多重 に形成させるとその自己集合挙動はどう変化するか？ その多くは, 界面同士の引力や水素結合形成により結晶 成長が促進され，ミクロスケール $\left(>10^{6} \mathrm{~nm}\right)$ の三次元 固体結晶となる（Fig. 1 (c))。しかしながら，水素結 合の特徴である弱い方向性, 相補性, 協同性 ${ }^{8)}$ を巧みに 分子内及び分子間相互作用に利用することにより，ナノ

$\left(1 \sim 10^{2} \mathrm{~nm}\right)$ からメゾスケール $\left(10^{2} \sim 10^{6} \mathrm{~nm}\right)$ の HARM を形成することが可能となる。我々は, 水素結 合形成を分子両端で多重に形成させるために，2 個の親 水部をアミド結合を介して疎水部に連結させる設計を 行った。これら双頭型脂質は好熱性細菌や古細菌の細胞 膜成分として含まれ，（1）多形現象がない，（2）最も 薄い単分子膜形成が可能である，（3）2 個の親水部の 非対称化によりべシクル膜を容易に形成する，（4）膜 融合が起こりにくい，（5）親水部構造を変化させて単 分子膜界面間の相互作用力を調節できる，（6）膜構造
を安定化させる，などの特徴をもつ。

Fig. 2 に, 我々が合成した各種の双頭型脂質の構造 式を, Table 1 に，それら合成脂質から主に水系媒体中 で得られた自己集合形態とサイズ次元をまとめた。以下， これら特異的な HARM 中での分子配列, 分子パッキン グ様式, 水素結合ネットワーク, 膜構造の界面相互作用 が及ぼす集合形態への影響などについて紹介する。

\section{4 双頭型糖脂質}

\section{$4 \cdot 1$ 水中でのらせん状ファイバー形成}

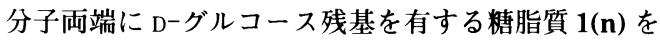
温水または熱水に溶解させ, その飽和水溶液を徐冷放置 すると繊維状集合体（ファイバー）または無定形固体が 自発的に形成する。暗視野, 位相差光学顕微鏡, 共焦点 レーザー走査型顕微鏡などを用いて，それらの集合形態 を観察評価した結果，連結鎖であるオリゴメチレン鎖の 長さに強く依存して，らせん状ファイバー $(\mathrm{n}=8,10$, and 12) (Fig. 3), 無定形 ( $\mathrm{n}=9$ and 13), 平板結晶 ( $\mathrm{n}$ =11）へと変化することを見いだした。この結果は, 従 来知られているキラルな分子集合体 ${ }^{9)}$ とは異なり，らせ ん状 HARM と非らせん集合体が連結炭化水素の炭素偶 奇数に応じて生成する, 新しい立体化学的効果を初めて 示したものとして興味深い10)。それら集合体の粉末 X 線回折ピークや赤外吸収スペクトルのメチレン基振動に 関与する特性ピークを解析した結果, オリゴメチレン鎖 のパッキング様式, アミド基の配向，アミド基間水素結 合力, 層状構造の長周期間隔において顕著な偶奇効果が 見られた。したがって，今回新たに見いだされた偶奇勃 果は分子が集合して形成する層状構造配列の相違（層状 多形) ${ }^{11)}$ に起因した層界面での糖鎖水素結合のキラル／ 
Table 1 Representative Morphologies of Self-Assembled Structures from Synthetic Bolaamphiphiles.

\begin{tabular}{|c|c|c|c|c|c|c|}
\hline $\begin{array}{c}\text { Hydrophilic } \\
\text { Moiety }\end{array}$ & Bolaamphiphile & \begin{tabular}{|c}
$\begin{array}{c}\text { Self-Assembled } \\
\text { Morphology }\end{array}$ \\
\end{tabular} & Solvent & Width (nm) & Length $(\mu \mathrm{m})$ & Reference \\
\hline Sugar & $\begin{array}{c}1(8), 1(10), 1(12) \\
1(9), 1(13) \\
1(11) \\
2(10), 2(12) \\
3(10), 3(12), 3(14) \\
3(11), 3(13) \\
4(9), 4(10), 4(11) \\
5\end{array}$ & $\begin{array}{c}\text { helical fiber } \\
\text { amorphous solid } \\
\text { platelet } \\
\text { needle crystal } \\
\text { helical fiber } \\
\text { thin ribbon, sheet } \\
\text { helical fiber } \\
\text { nanofiber }\end{array}$ & $\begin{array}{c}\text { water } \\
\text { water } \\
\text { water } \\
\text { water } \\
\text { water/ethanol(1/1) } \\
\text { water/ethanol(1/1) } \\
\text { water } \\
\text { ethyl acetate/n-hexane }(3 / 7) \\
\end{array}$ & $\begin{array}{l}30 \sim 3000 \\
\text { n.d. } \\
3 \times 10^{5} \\
\sim 5 \times 10^{4} \\
8 \sim 25 \\
10 \sim 150 \\
30 \sim 100 \\
6 \sim 30\end{array}$ & $\begin{array}{c}\sim 1000 \\
\text { n.d. } \\
\sim 800 \\
\sim 90 \\
\sim 20 \\
\sim 20 \\
\sim 1000 \\
\text { n.d. }\end{array}$ & $\begin{array}{l}\text { 10) } \\
10) \\
15) \\
16) \\
12) \\
12) \\
\text { u.p. } \\
18)\end{array}$ \\
\hline Peptide & \begin{tabular}{|c|}
$6(6), 6(8), 6(10)$ \\
$6(6), 6(8), 6(10)$ \\
$6(10)$ \\
$6(10)$ \\
$7(6), 7(10)$ \\
$8,9,10,11$ \\
$12(n)(n \geq 7)$ \\
$13(8)$ \\
$14(8), 14(10), 14(12)$ \\
\end{tabular} & $\begin{array}{l}\text { microtube } \\
\text { vesicle } \\
\text { rod-like micelle } \\
\text { needle } \\
\text { microtube } \\
\text { solution } \\
\text { nanofiber } \\
\text { ribbon } \\
\text { nanofiber } \\
\end{array}$ & $\begin{array}{l}\text { water }(\mathrm{pH} 7-10) \\
\text { water }(\mathrm{pH} 7-10) \\
\text { water }(\mathrm{pH} 7-10) \\
\text { water }(\mathrm{pH} 7-10) \\
\text { water }(\mathrm{pH} 7-10) \\
\text { water }(\mathrm{pH} 7-10) \\
\text { water }(\mathrm{pH} 7-10) \\
\text { water }(\mathrm{pH} 5-6) \\
\text { water }(\mathrm{pH} 5-6)\end{array}$ & \begin{tabular}{|c|}
$1000 \sim 3000$ \\
$100 \sim 3000$ \\
10 \\
$20 \sim 50$ \\
$\sim 1000$ \\
n.d. \\
$10 \sim 15$ \\
$10^{3} \sim 10^{5}$ \\
$10 \sim 15$ \\
\end{tabular} & $\begin{array}{c}\sim 1000 \\
0.1 \sim 3 \\
0.05 \sim 0.3 \\
2 \sim 10 \\
\sim 1000 \\
\text { n.d. } \\
\sim 10 \\
\sim 1000 \\
\sim 10\end{array}$ & $\begin{array}{c}\text { 20) } \\
22) \\
22) \\
24), 26) \\
22) \\
22 \text { ) } \\
30), 31 \text { ) } \\
32 \text { ) } \\
32) \\
\end{array}$ \\
\hline Nucleobase & $\begin{array}{c}16(10) \\
17(\mathrm{n}) \\
18(12) \\
\end{array}$ & $\begin{array}{c}\text { double-helical rope } \\
\text { microcrystal } \\
\text { nanofiber }\end{array}$ & $\begin{array}{l}\text { water/ethanol(9/1) } \\
\text { water/ethanol(9/1) } \\
\text { water/ethanol(1/1) }\end{array}$ & $\begin{array}{c}200 \sim 1000 \\
10^{3} \sim 10^{4} \\
15 \sim 150 \\
\end{array}$ & $\begin{array}{c}\sim 1000 \\
1 \sim 10 \\
15 \sim 100 \\
\end{array}$ & $\begin{array}{l}36) \\
36) \\
38) \\
\end{array}$ \\
\hline Other & $15(n)$ & nanofiber, microcrystal & water & n.d. & n.d. & u.p. \\
\hline
\end{tabular}

n.d. $=$ not determined. u.p. $=$ unpublished.

非キラル性に起因するものと考えた。

集合形態に及ぼす連結オリゴメチレン鎖の炭素数偶奇 効果は，その連結鎖の架橋位置をグルコピラノース環の 1 位から 2 位に変えた D-グルコサミンから誘導した双 頭型脂質 3(n) においても同様に観察できた ${ }^{12)}$ 。しかし， 架橋位置のわずかな変化は, 水素結合ネットワークの大 きな構造変化を引き起こし, その結果, 3(n)の水への 溶解性は1(n) に比べて大きく減少することがわかった。

\section{$4 \cdot 2$ 分子配列と水素結合ネットワーク}

これらの自己集合ファイバーは空気中に単離可能であ る。また, 水中でのアルキル鎖の融点（ゲルー液晶相転 移温度）は示さず, 空気中で約 $220^{\circ} \mathrm{C}$ 付近まで安定で ある。なぜ，これまでに安定な集合体構造をしているの か? 親水部が単糖で, 疎水部が直鎖状飽和炭化水素(炭 素数が 5 以上）から構成される糖脂質の $\mathrm{X}$ 線単結晶構 造は，これまでにわずか数例しか知られていない(13)。し かも, その全てのアルキル鎖が指組構造 (interdigitated) をした頭一頭不完全二分子膜構造をとることが知られ る ${ }^{14)}$ 。ところが, 2 個の糖残基を 1 本のオリゴメチレン 鎖で連結した場合, このような指組構造をとることは不 可能である。

1(11) は双頭型糖脂質として初めて単結晶構造を与え た。その結果, 分子は層面法線から大きく傾いて (約 $\left.49^{\circ}\right)$ 最密充填し，プリーツ状の層状構造を形成していること がわかった (Fig. 4) ${ }^{15)}$ 。単分子膜構造の層内にはアミ
ド基と糖鎖 2 位のヒドロキシル基が関与した一次元的な 水素結合鎖が，層間にはそれと直交する面内で残りの糖 鎖ヒドロキシル基が関与した二次元的な水素結合ネット ワークが関与していた。興味あることに,グルコピラノー ス環上の 4 位ヒドロキシル基の立体化学をエクアトリア ル位からアキシアル位に変化させるだけで（エピマー関 係), 分子間水素結合ネットワークは全く様相を変え, 二次元的から三次元的に変化することを見いだした ${ }^{16)}$ 。

透過型電子顕微鏡観察より ${ }^{17)}, 1(12)$ から形成するファ イバーの最小基本単位は, 厚さ約 $3 \mathrm{~nm}$ の単分子膜リボ ンが幅約 $35 \mathrm{~nm}$ の右巻きらせんを形成したナノファイ バーであることを確認した ${ }^{10)}$ 。1(12) から形成するファ イバーの X 線回折から得られた長周期間隔 $(d=2.45$ nm）と1(11)の結晶構造を考虑して，Fig. 5 に示した ファイバー中の分子配列を推定した。この最小ナノファ イバーが 8 本束なりより高次の繊維集合体に会合してい る様子もクライオ電子顕微鏡観察より確認できた。こう して,コラーゲン繊維などの繊維状タンパク質と同様に， 階層的な高次組織化によって自己集合ファイバーが構築 されていることが明らかとなった ${ }^{17)}$ 。

\section{$4 \cdot 3$ 重合性双頭型糖脂質を用いた分子ワイヤー形成}

分子短軸方向での一次元的自己集合とそれをナノテン プレートとした重合反応を組み合わせれば，高分子一本 鎖構造を形成することが可能となる。

ジアセチレン基を含む長鎖ジカルボン酸の両端にアミ 


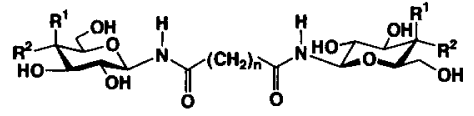

1(n): $R^{1}=H, R^{2}=O H(n=6,9,10,11,12,13,14$, and 18) 2(n): $R^{1}=O H, R^{2}=H(n=10,11$, and 12)

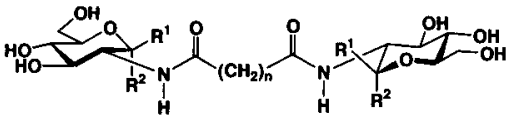

(n $=9,10,11,12,13,14,16$, and 18 )

3(n): $R^{1}=H, R^{2}=O H$ ( $\alpha$-anomer)

$\mathrm{R}^{1}=\mathrm{OH}, \mathrm{R}^{2}=\mathrm{H}$ (8-anomer)

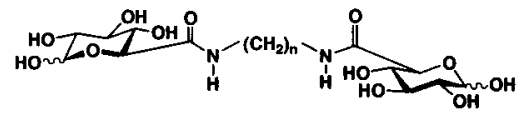

4(n): $(n=9,10,11,12,13,14,16$, and 18)
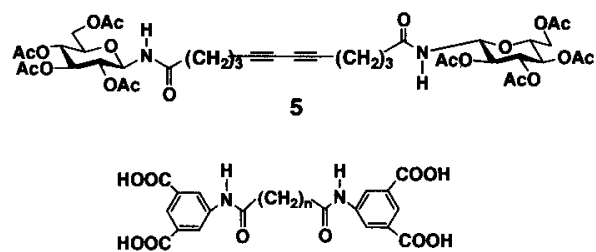

$15(n):(n=2,3,4,5,6,7,8,9,10,11$, and 12)

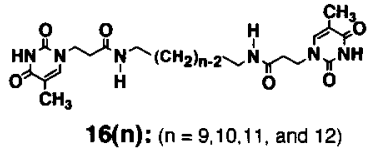

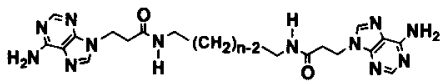

17(n): $(n=9,10,11$, and 12)

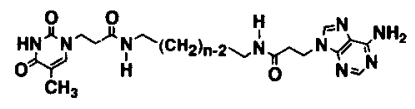

18(n): $(n=9,10,11$, and 12$)$

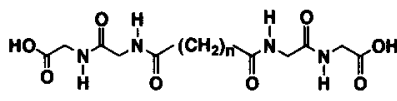

$6(n):(n=6,8,9,10,11,12$, and 14$)$<smiles>O=C(O)CNC(=O)CNC(=O)CNC(=O)CCCC(=O)NCC(=O)NCC(=O)NCC(=O)NCC(=O)O</smiles>

$7(n):(n=6$ and 10$)$
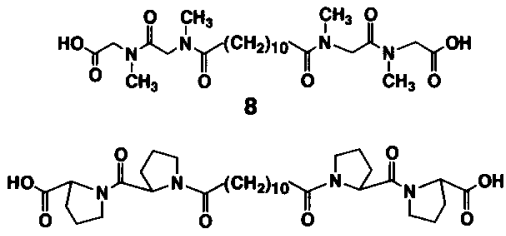

9
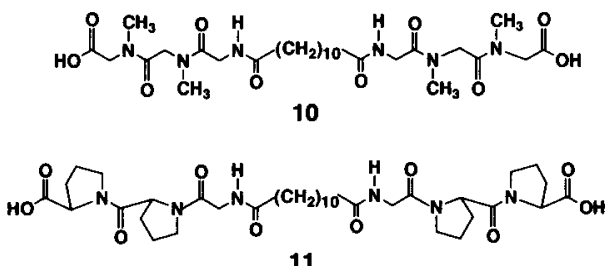

11

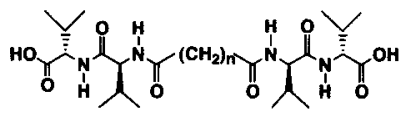

12(n): ( $n=4,5,6,7,8,9,10,11$, and 12)
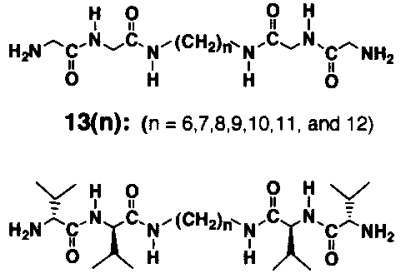

14(n): $(n=8,10$, and 12)

Fig. 2 Molecular Formulas of Synthetic Bolaamphiphiles.
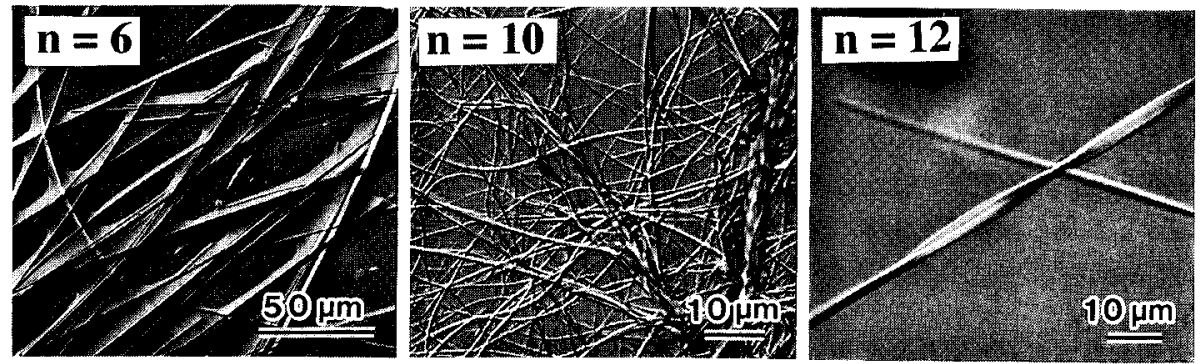

Fig. 3 Self-assembled Helical Fibers Made of 1(n) $(n=6,10$, and 12) Observed Using Confocal Laser Scanning Microscopy (in water at $25^{\circ} \mathrm{C}$ ). 


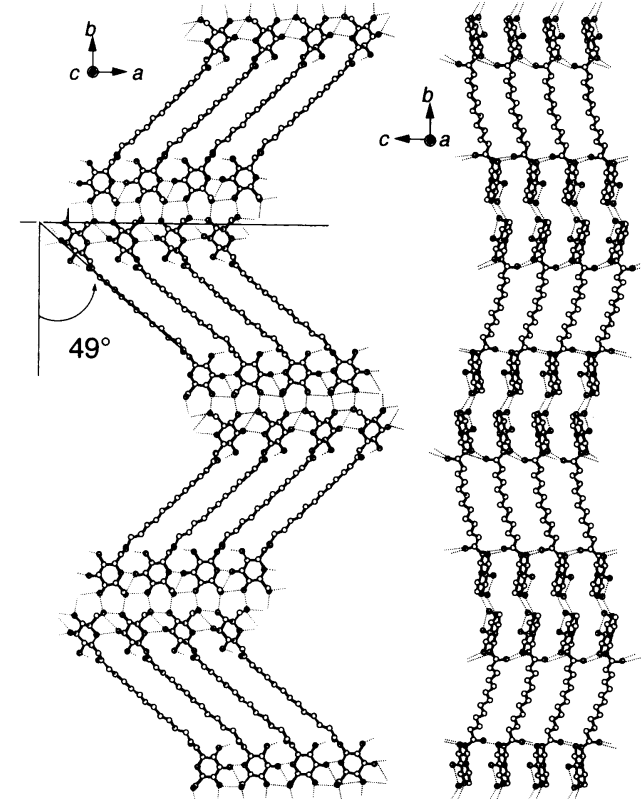

Fig. 4 X-ray Crystal Structure of 1(11) Viewed Along the $c$ - (left) and the $a$-axis (right). Hydrogen bond networks are denoted.

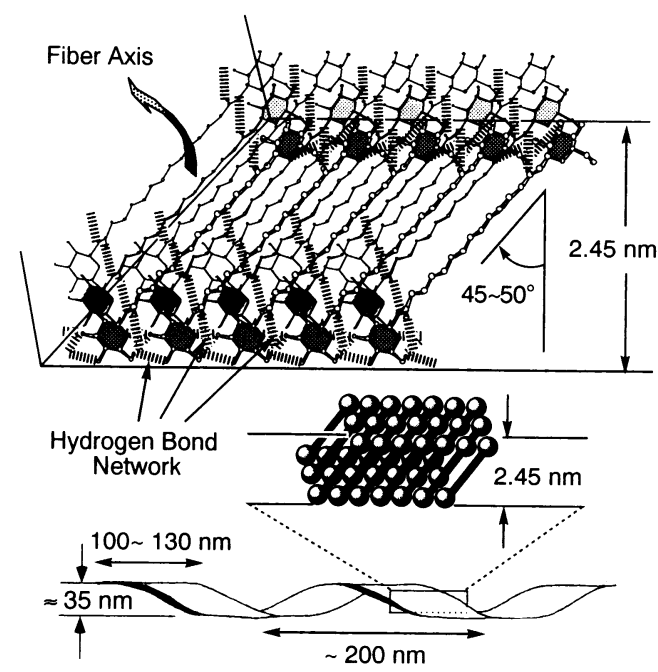

Fig. 5 A Possible Self-assembled Model of 1(12) Based on Monolayered Chiral Sheet.

ド基を介して $\mathrm{D}$-グルコース残基が連結した重合性のア セチル化双頭型糖脂質 5 を合成した。 5 は酢酸エチル／ n-へキサンなどの有機溶媒と混和することにより, 約 6 〜20 nm 幅のナノファイバーから構成される有機ゲルを 形成する。ナノファイバー中で，分子は両端アミド基の 一次元的水素結合形成を介して梯子状に分子が充填して
いることがわかった（Fig. 6 (a))。このゲルの有機溶 媒分散液に $\gamma$ 線または紫外線 $(254 \mathrm{~nm})$ を照射した結果, ナノファイバーはその繊維状形態を保持したまま重合反 応を起こすことがわかった（Fig. 6 (b) ) $)^{18)}$ 。分子 5 が 単分散状態にあるクロロホルム溶液から得たキャスト膜 中では重合反応が全く見られなかったことから，一次元 自己集合構造を鋳型として共有結合性のナノファイバー が形成することを確認した。重合後のナノファイバーの 最小幅は5 の分子長に相当する約 $3 \mathrm{~nm}$ であり, 高分子 一本鎖の幅を意味する。ファイバー中心部に導電性部位 を含み, 外部は絶縁層であるアセチル化単桾によって被 覆されているため, 導電性分子ワイヤーとして注目でき る $^{19)}$ 。

\section{5 双頭型ペプチド脂質}

$5 \cdot 1$ 双頭型グリシン脂質のマイクロチューブ形成

分子両端にグリシンの二量体, 三量体を有するジカル ボン酸型脂質 6(n), 7(n) のナトリウム塩は水中で, 内 部に多数の球状小胞体 (ベシクル) を内包する直径が 1 $\sim 3 \mu \mathrm{m}$, 長さが数百 $\mu \mathrm{m}$ の閉じたチューブ状集合体（マ イクロチューブ）を与える20) (Fig. 7)。特に，6(10)の 場合, チューブ外壁から幅 20〜 $50 \mathrm{~nm}$, 長さが 2 10 $\mu \mathrm{m}$ の極微小の針状結晶が所々，析出している様子が観察で きた（Fig. 7 (a)，矢印)。合成脂質の自己集合によっ てチューブ構造が形成する例は非常に数少ない211。しか も, ベシクルが内部にカプセル化した光学顕微鏡サイズ の単離可能な有機マイクロチューブは従来報告例が全く ない。この有機マイクロチューブ形成にとってグリシル グリシン残基の存在は不可欠であり，他のアミノ酸残基 を含む脂質，8，9，10，11，さらには奇数鎖をもつ脂質 6(9), 6(11) はチューブ形成能をもたないことが大きな 特幑である22)。

\section{$5 \cdot 2$ マイクロチューブの形成機構}

チューブ膜内において分子末端カルボン酸はそのアニ オンと分子間水素結合を形成していることがわかった。 一般に長鎖脂肪酸の水中における自己集合挙動はカルボ キシル基のイオン化度 $(\alpha)$ に大きく依存することが知 られる。例えば，完全にイオン化した脂肪酸（石敛） $(\alpha$ $=1.0)$ は水中でミセル, 液晶, 稀に結晶を形成するの に対し，全くイオン化していない脂肪酸 $(\alpha=0)$ は油 滴または結晶を形成する。しかし，イオン化度がその中 間值 $(0<\alpha<1.0)$ をとる時の集合挙動については不明 な点が多い23)。そこで, 今回用いた双頭型グリシン脂質 6(n) を含む水溶液の $\mathrm{pH}$ とイオン化度 $(\alpha)$ との相関関 係を求めた。その結果，6(6) の場合では， $\alpha=0.8 \sim 0.9$ の範囲でマイタロチューブ形成が起こり，それ以上プロ トン化が進行 $(\alpha<0.7)$ すると結晶化が起こることが わかった22)。 


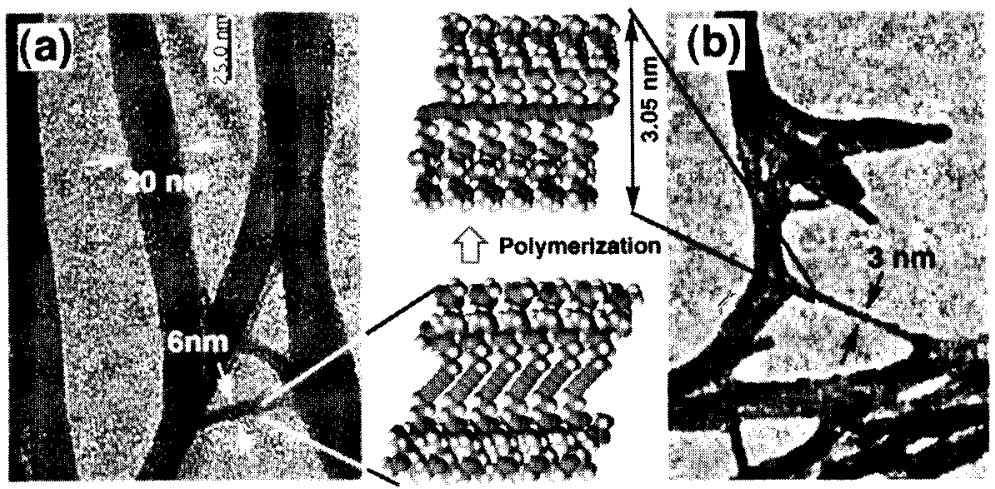

Fig. 6 (a) Self-assembled (unpolymerized) Nanofibers Made of 5 and (b) $\gamma$-ray-irradiated (polymerized) Fibers of 5 Observed Using EF-TEM.
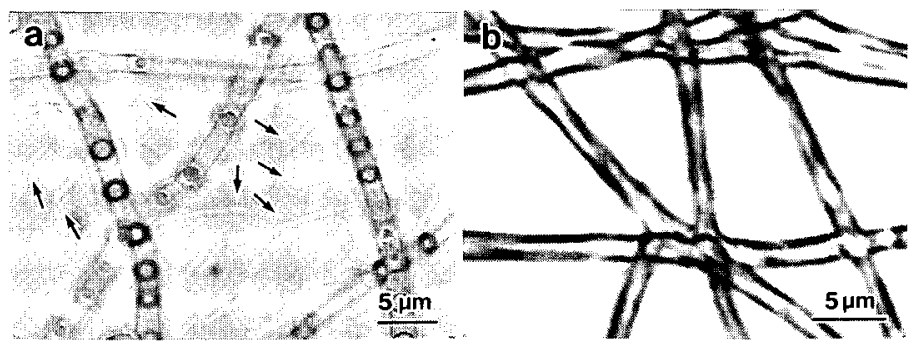

Fig. 7 Organic Microtubes Made of 6(10) Observed Using Phasecontrast Light Microscopy ; (a) in Water at $25^{\circ} \mathrm{C}$ and (b) after Vacuum Drying.

以上の $\mathrm{pH}$ 滴定解析をもとに，マイクロチューブ及び 外壁上に析出した針状結晶の形成機構を推定した。熟成 開始直後, ロッド状ミセルとして溶解していたジカルボ ン酸アニオン型脂質はゆっくりとプロトン化を受け，酸 一アニオン型の分子間水素結合を単分子膜層内に形成す る (Fig. 8 (a))。グリシン残基間の分子間水素結合に も支持されて，千ューブ状構造体を安定化させる。さら に，プロトン化が進行するとチューブ外壁界面において 酸一酸型の水素絬合様式への変換が生じ（Fig. 8(b)), 針状結晶が表面上に析出したと考えられる。一方, チュー ブ内部の球状べシタルはチューブ内壁における内層部の 層状欠陥を契機としてエネルギー的により有利な球状構 造をとったと推定できる22)。

$5 \cdot 3$ チューブと結晶中の水菜結合ネットワーク

希酢酸の蒸気抎散を用いて 6(10)のチューブ表面上に 析出した針状結晶の単結晶化に成功し, X 線単結晶構造 解析を行った。その結果, 分子は $2.72 \mathrm{~nm}$ の長周期間隔 をもつ層状構造をとり, 末端カルボン酸は層間で酸一酸 型の分子間水素結合を形成していることがわかった (Fig.9 (a)，(b))。分子は最近接する周团の6 分子と グリシン残基のアミド基間で分子間水素結合を形成し, (a) Intralayer acid-anion interaction

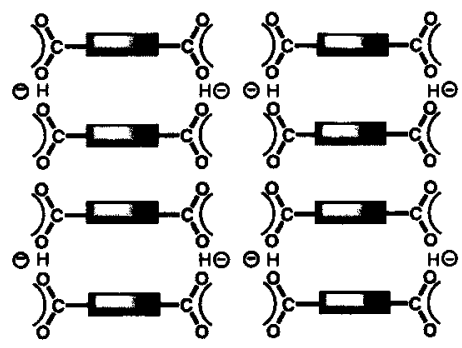

(b) Interlayer acid-acid interaction

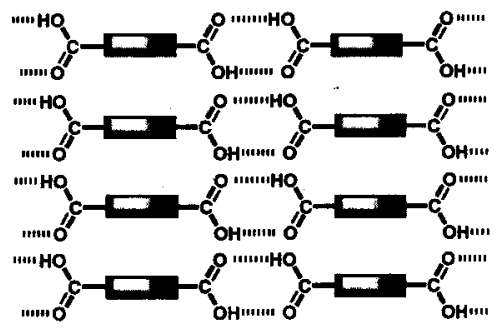

Fig. 8 Schematic Representation of the Monolayer Interaction. 
(a)

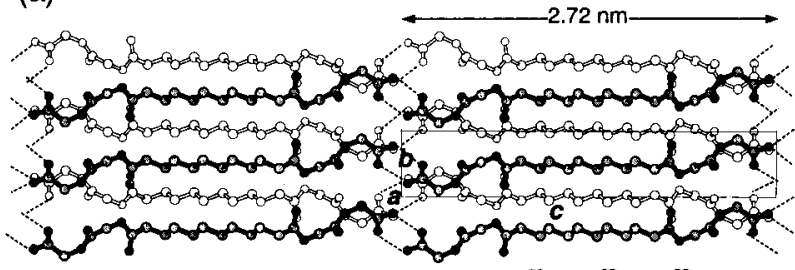

(b)

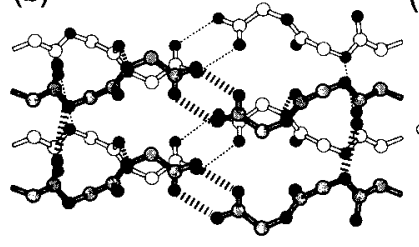

(c)

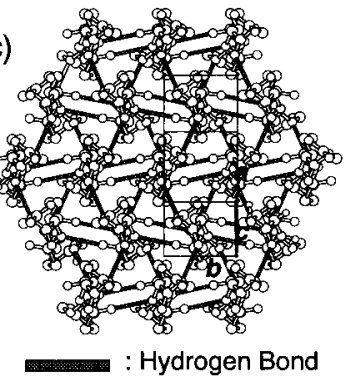

Fig. 9 X-ray Crystal Structure of 6(10). (a) Projected on the $b c$ plane, (b) magnification of the terminal glycylglycine moieties, and (c) projected on the $b(2 a / 3+1 c / 8)$-plane.

ヘキサゴナル格子をとる（Fig.9（c)）。ポリグリシン は他のポリアミノ酸とは異なり, 特異的なへキサゴナル 格子 (ポリグリシン II 型構造) 25)を形成することが知ら れる。したがって，この結果は低分子の自己集合により 初めてポリグリシン II 型構造を自発的に形成したことを 意味する ${ }^{26 ! 。}$

一方，マイクロチューブ中では, 頭部グリシン間の水 素結合ネットワークに㰞陷部が存在することがわかっ た。高分解能の原子間力顕微鏡観察より膜原は伸張型分 子の全長の 30 ～ 40 層分に相当する約 $100 \mathrm{~nm}$ であり，ぺ プチド頭部はチューブ膜表面において㫫んだへキサゴナ ル型パッキングをしていることがわかった（Fig. 10) 222。 チューブ膜の深さ方向に対する分子レベルでの原子間力 顕微鏡（AFM）観察を行った。その結果，単結晶構造 においては単分子膜の層間分子間相互作用が支配的であ るのに対し，このチューブ状構造においては層内分子間 相互作用が支配的であることを初めて直視することがで きた27)。さらに，双頭型糖脂質のファイバー形成之同㥞 に，チューブ構造においても，屈曲型分子一層状構造一 カラム状ドメイン構造一チューブ膜と階層的な高次構造 形成を起こしていることが $\mathrm{AFM}$ 評価より明らかとなっ た。

\section{4 双頭型バリン脂買のナノファイバー形成}

ジペプチド，トリペプチド，あるいはポリペプチド残 基を含む両親媒性化合物の自己集合挙動の研究は，そも そも国武らの合成二分子膜形成物質を用いた先駆的な研 究に端を発す ${ }^{28)}$ 。一般に, ペプチド残基が関わる二次， 三次構造は集合形態に大きな影響を与える299。 また, ジ

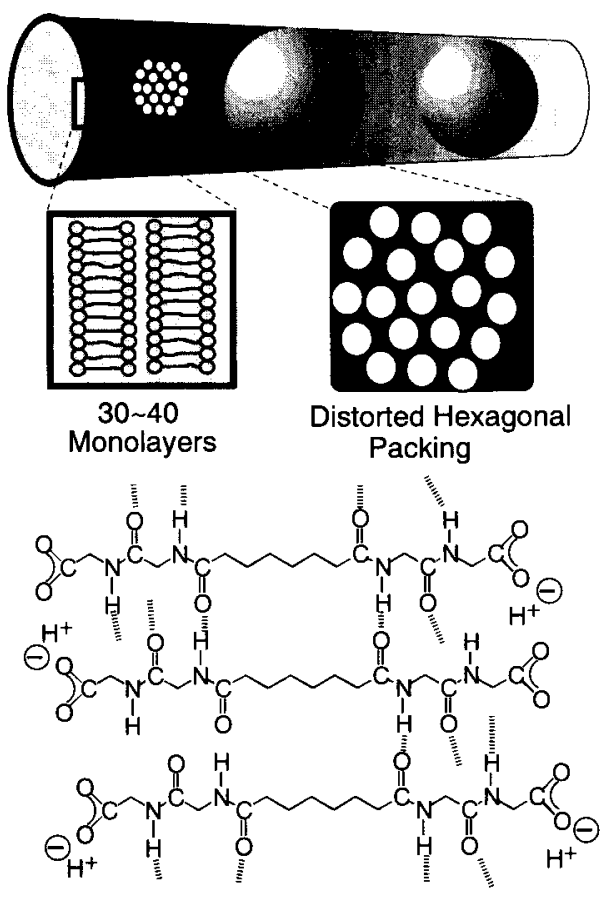

Fig. 10 Self-assembling Structure of 6(10) Within the Microtube Membrane.

カルボン酸親水部の場合, 単分子膜層内, 層間の水素結 合様式が集合構造を支配する22)。

そこで，へキサゴナル型水素結合様式をとったグリシ ルグリシン残基に変えて, $\beta$-シート型構造をとると予 
想できる $\mathrm{L}^{-}$バリルー-バリン残基を分子両端に含むジカ ルボン酸型脂質 12(n) を合成し，水中でのプロトン化を 駆動力とする自己集合挙動を検討した。その結果， 12(6) は結晶性の沈殿を与えるのみであったが，12(n)

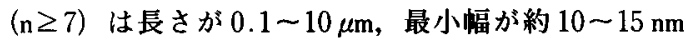
の無数のナノファイバーから構成されるヒドロゲルを形 成することを見いだした ${ }^{30) 。 ナ ノ フ ァ イ ハ ゙ ー 中 て ゙ ， ハ ゙ リ ~}$ ルバリン部は $\beta$-シート構造を形成していることが確認 できた。さらに，栤外吸収スペクトルのカルボニル基の 伸縮振動を詳しく解析することにより，12(n)（n２7) が形成するナノファイバーでは，層内での横方向のカル ボン酸一カルボン酸型の水素結合形成が支配的であるこ とを見いだした。これに対し，12(4)，12(6)の場合，層 間相互作用が強くなり，三次元的に成長した結晶を与元 ることがわかっだ1!。

一方，N端を分子末端にもち，グリシルグリシンある いは L-バリル-L-バリン残基を含むジアンモニウム塩型 双頭型脂質 13(n)，14(n) を合成し，脱塩化水素を駆動 力とする自己集合についても検討した。その結果，バリ ルバリン型脂質のみが偶数鎖においてナノファイバーを 与えた。末端アミノ基間と末端カルボキシル基間の水素 結合様式の相違を反映させて，13(8)の場合は 6(n), 7(n) が示したチューブ構造を形成する代わりに少し湾 曲したリボン状集合体を与えた ${ }^{322}$ 。

\section{6 双頭型核酸塩基脂質}

\section{$6 \cdot 1$ 相補的な分子認識を利用した HARM 構築}

非共有結合性相互作用として相補的な水素結合形成に 基づく分子認識を利用して，例光ば超分子液晶あるいは メゾスコピック系組織体を構築できる。最近の研究展開 に関しては, 加藤・木原 ${ }^{33)}$ や君塚の総説 ${ }^{34)}$ をびひ参照穎 いたい。ここでは，従来研究例がないチミン一チミン， チミンーアデニン，アデニンーアデニン核酸塩基間相互 作用に基づく階層的な HARM 構築の例について述心゙ る。上記で述べたのと同様な分子設計に基づき，チミン （T）またはアデニン残基（A）をアミド結合を介して 長鎖ジアミンと連結させた対称型の核酸塩基脂質 $16(n), 17(n)$ ，及び非対称型の脂質 18(n) 合成した。
これら脂質を用いることにより，単分子膜間に働くと予 想できる核酸塩基間相互作用の強さ（ $\mathrm{T}-\mathrm{T}<\mathrm{T}-\mathrm{A}<\mathrm{A}-\mathrm{A}$ の順に大きくなる ${ }^{35}$ を非静電的に変化させた時の自己 集合形態に及ぼす影锌を調べることができる。

$6 \cdot 2$ 対称型チミン脂睤の二重らせんロープ形成

17(10) が水/エタノール (9/1, 容稹比) 中で自己集 合（木モ集積）らより与える構造は微結唱性固体である のに対し，16(10) 愊が約 $2 \mu \mathrm{m}$ に達し，長さが数百 $\mu \mathrm{m}$ の, DNA 二重らせん構造に比べると巨大な二重らせ んロープ構造を与えることを見いだした ${ }^{30)}$ (Fig. 11

(a))。長期間（1 年以上）安定に形態を保持し，かつ メゾスケールの二重らせん構造を分子の自己集合により 形成させたのはこれが最初の例かもしれない。透過型電 子顕微鏡観察より，この二重らせんロープは直径が約 10 15 nmのナノファイバー単位がさらに高次に集積化 して直径 $0.2 \sim 1 \mu \mathrm{m}$ の織維束を形成し，その二本が同 じ方向に巻きあがったものであることが明らかとなっ た。一方，16(10) と 17(10)の $1: 1$ (モル比）混合物の 自己集合 (ヘテロ集積) は幅が $10 〜 20 \mathrm{~nm}$ のナノファイ バーのみを与えた (Fig. 11 (b))。こうして, 二重らせ んロープ棈造がチミンの相補的成分であるアデニン成分 の共存下で阻止される現象を見いだした。'H-NMRを 用いた成分分析より，16(10) は木モ集積中に自然光に より両端チミン残基が光二量化反応を起こし，生成した ごく少量のエナンチオメリックな光反応物がトリガーと なってキラルな二重らせんロープを誘起したと推定でき た。しかし，17(10)の存在下では，16(10)は17(10)と の相補的な水素結合形成のためチミン残基が光二量化に とって不都合な配置・配向をとり，その結果，チミン残 基の光二量化が阻止されたと考えられる37。

6.3 非対称型脂彊のナノファイバー形成

一方，非対称型である18(10)のホモ集稹は同じ核酸 塩基間相互作用に基づく 16(10) と17(10) とのへテロ集 積で見られたナノ紻維形成は認められなかった。しかし， 連結鎖を長くすることで 18(12) は同様なナノファイ

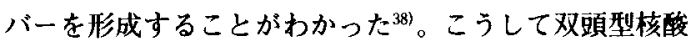
塩基脂質は塩基間相互作用の強さ及び構成分子の成分数 に応じて敏感に形態変化を起こすことがわかった。

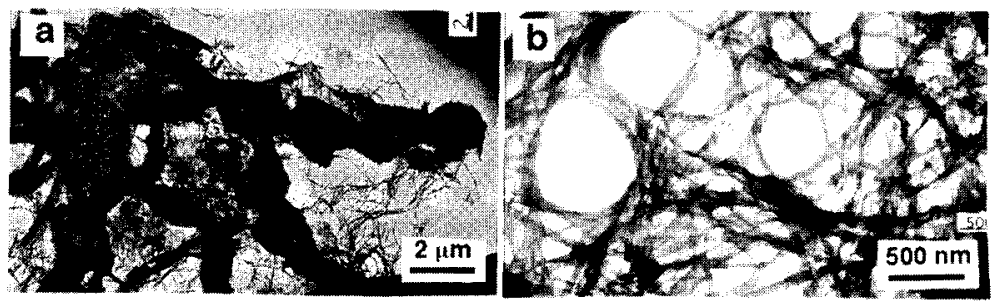

Fig. 11 (a) Double-helical Ropes and (b) Nanofibers Made of 16(10) and a $1: 1$ mixture of $16(10)$ and $17(10)$, respectively. 
16(10) と 17(10) との $1: 1$ へテロ集積体の赤外吸収ス ペクトル及び粉末 X 線回折結果は, これら両分子が核 酸塩基間で相補的な水素結合を形成し，長周期間隔が $d$ $=5.06 \mathrm{~nm}$ の層状構造をとっていることを支持した。こ うして一次元的なアミド基水素結合連鎖が DNA 中のオ リゴヌクレオチド鎖 ${ }^{39}$ と同様に, 核酸塩基間のスタッキ ングと 2 本鎖型の核酸塩基塩基間水素結合形成の両方の 安定化に大きく寄与しているが示唆された。

$$
7 \text { おわりに }
$$

糖, ペプチド, 核酸塩基は生体材料構成要素として重 要な役割を果たしている。それらを分子両端にもち，ア ミド基を介して長鎖のオリゴメチレン鎖に連結させた双 頭型脂質の水系での自己集合挙動とその特徴について述 ベた。これら分子はナノからメゾスケールの領域にタン パク質の繊維状自己組織化構造と全く同様なサイズ分布 をもって，各種の HARM を形成することがわかった。 水素結合の数, 方向性を制御して単分子膜間の界面に働 く相互作用力を弱めることにより，種々の形態をもつ繊 維状構造を合成することが可能である。一方, 界面間の 相互作用を強めることにより容易に三次元結晶構造を与 えた。ここでは筆者らの研究を中心に解説したが, 水素 結合が関与する種々の特異的な構造形成の魅力はこの拙 論では語りきれない。ぜひとも，他の優れた解説書 ${ }^{8)}$.39) や総説40)を参考にして頂きたい。

$$
\text { 謝辞 }
$$

本稿の双頭型脂質に関する研究は，増田光俊，小木曽 真樹各研究員, 浅川真澄博士（物質研ポリマーオブジェ クトグループ)，八瀬清志, 岡田祐二, 大西里実, 芝上 基成, 後藤みどり，本田一匡各博士（物質研），花田 剛博士（現大阪大学産業科学研究所）, 中澤郁郎, 須田 栄, 岩浦里愛研究員 ((財) 化学技術戦略推進機構) との 共同研究によるものであり,ここに厚く感謝申し上げる。

(受付：2000 年 4 月 27 日, 受理 : 2000 年 6 月 15 日)

\section{文献}

1) 宝谷紘一，伊藤知彦，“コロイド科学「生体コロイ ドおよびコロイドの応用」”東京化学同人，東京 (1996) 第 7 章.

2) T. Shimizu, "Polymer Objects: Toward New Polymer Architectures in New Aspects of Macromoelecular Science and Engineering", Springer, Berlin (1999) p. 53 ; J. M. Schnur, R. Shashidhar, Adv. Mat., 6, 971 (1994).

3) 清水敏美, 増田光俊, 小木曾真樹, 浅川真澄, 高 分子論文集，54，815 (1997)； T. Shimizu, Trans. Mat. Res. Soc. Jpn., 24, 431(1999).
4) 例えば, J. H. Fendler, “Membrane Mimetic Chemistry”, Wiley, New York (1982).

5) J. N. Israelachivili, "Intermolecular and Surface Forces”, Academic Press, New York (1985).

6) 清水敏美, 表面科学, 19, 222 (1998).

7) J. -H. Fuhrhop, Chem. Rev., 93, 1565 (1993) ; J. -H. Fuhrhop, J. Koening, "Membranes and Molecular Assemblies: The Synkinetic Approach", The Royal Society of Chemistry, Cambridge (1994).

8) G. A. Jeffrey, W. Saenger, "Hydrogen Bonding in Biological Structures", Springer-Verlag, Berlin (1991).

9) T. Tachibana, T. Yoshizumi, K. Hori, Bull. Chem. Soc. Jpn., 52, 34 (1979); N. Nakashima, S. Asakuma, T. Kunitake, J. Am. Chem. Soc., 107, 509 (1985).

10) T. Shimizu, M. Masuda, J. Am. Chem. Soc., 119, 2812 (1997).

11）佐藤清隆，小林雅通，“脂質の構造とダイナミクス” 共立出版，東京，(1992) p. 34.

12) I. Nakazawa, M. Masuda, Y. Okada, T. Hanada, K. Yase, M. Asai, T. Shimizu, Langmuir, 15, 4757 (1999).

13) G. A. Jeffrey, L. M. Wingert, Liq. Cryst., 12, 179 (1992).

14) P. C. Moews, J. R. Knox, J. Am. Chem. Soc., 98, 6628 (1976).

15) M. Masuda, T. Shimizu, Chem. Commun., 1996 , 1057 ; M. Masuda, T. Shimizu, Carbohydr. Res., 302, 139 (1997).

16) T. Shimizu, M. Shibakami, M. Masuda, Chem. Lett., 1997, 267 ; M. Masuda, T. Shimizu, Carbohydr. Res., 326, 56 (2000).

17）清水敏美，八瀬清志，大西里実，増田光俊，小木 曽真樹, 浅川真澄, 浅井道彦, 中澤郁郎, 岩浦里愛, 高分子論文集, 56, 575 (1999) ; 花田 剛, 岡田祐二, 八瀬清志, 日本油化学会誌, 47, 1115, (1998).

18) M. Masuda, T. Hanada, K. Yase, T. Shimizu, Macromolecules, 31, 9403 (1998).

19）伊藤耕三，下村武史，化学と工業，52，1170 (1999).

20) T. Shimizu, M. Kogiso, M. Masuda, Nature, 383, 487 (1996).

21) P. Yager, P. Schoen, Mol. Cryst. Liq. Cryst., 106, 371 (1984) ; J. M. Schnur, Science, 262, 1669 (1993) ; T. Imae, K. Funayama, M. P. Krafft, F. Giulieri, T. Toda, T. Matsumoto, J. Colloid Interf. Sci., 212, 330 (1999).

22) M. Kogiso, S. Ohnishi, K. Yase, M. Masuda, T. Shimizu, Langmuir, 14, 4978 (1998).

23) 例えば, D. P. Cistola, D. Atkinson, J. A. Hamilton, D. M. Small, Biochemistry, 25, 2804 (1986).

24) M. Kogiso, M. Masuda, T. Shimizu, Supramol. Chem., 9, 183 (1998). 
25) F. H. C. Crick, A. Rich, Nature, 176, 780 (1955) ; E. Navarro, V. Tereshko. J. A. Subirana, J. Puiggali, Biopolymers, 36, 711 (1995).

26) T. Shimizu, M. Kogiso, M. Masuda, J. Am. Chem. Soc., 119, 6209 (1997).

27) T. Shimizu, S. Ohnishi, M. Kogiso, Angew. Chem. Int. Ed. Engl., 37, 3260 (1998).

28) T. Kunitake, N. Yamada, J. Chem. Soc., Chem. Commun., 1986, 655 ; T. Kunitake, Angew. Chem. Int. Ed. Engl., 31, 709 (1992).

29) N. Yamada, K. Ariga, M. Naito, K. Matsumoto, E. Koyama, J. Am. Chem. Soc., 120, 12192 (1998).

30) M. Kogiso, T. Hanada, K. Yase, T. Shimizu, Chem. Commun., 1998, 1791.

31) M. Kogiso, Y. Okada, T. Hanada, K. Yase, T. Shimizu, Biochim. Biophys. Acta, 1475, 346 (2000).

32) 小木曾真樹, 岡田祐二, 増田光俊, 八瀬清志, 清
水敏美, Polym. Prepr. Jpn., 48, 1261 (1999).

33）加藤隆史, 木原秀元, 表面科学, 19, 230 (1998).

34) 君塚信夫, 表面科学, 19, 237 (1998).

35) M. P. Schweizer, S. I. Chan, P. O. P. Ts'o, J. Am. Chem. Soc., 87, 5241 (1965).

36) T. Shimizu, R. Iwaura, M. Masuda, Polym. Prepri., ACS., 40, 1144 (1999).

37) Y. Kita, Y. Inaki, K. Takemoto, J. Polym. Sci., Polym. Chem. Ed., 18, 427 (1980).

38）岩浦里愛, 増田光俊, 岡田祐二, 八瀨清志, 清水 敏美, Polym. Prepr. Jpn., 49, in press, “相補的な 核酸塩基を分子両端にもつ非対称双頭型脂質の ファイバー形成”.

39) W. Saenger, "Principles of Nucleic Acid Structure”, Springer, Berlin (1984).

40) 日本表面科学会編, 表面科学, 特集号 “水素結合 による超分子構築” 19, 221 (1998). 


\title{
[総説 $]$
}

\section{糖・ペプチド・核酸系双頭型 脂質の構造形成}

\author{
清 水 敏 美 \\ 物質工学工業技術研究所有機材料部 \\ ポリマーオブジェクトグループ \\ （テ305-8565 茨城県つくば市東 1-1）
}

糖, ペプチド, 核酸塩基要素が疎水性スペーサの両端に連結した種々の双頭型脂質を合成した。それらは水溶 液中で自己集合し，熱的に安定な，ナノメータースケールのらせん状ファイバー，チューブ状ファイバー，二重 らせんロープなどの高軸比構造体（HARM=High-Axial-Ratio Microstructures）を形成した。それら構造体のサ イズ分布はコラーゲン繊維, 細菌鞭毛,アクチン繊維など生体系の自己集合繊維構造体と同等である。さらに, それら自己集合形態は用いたオリゴメチレン鎖スペーサの長さと炭素偶奇数に強く依存する。HARM 中の分子 配列および水素結合ネットワークを赤外吸収，粉末 X線回折，原子間力顕微鏡によって解析した。その結果，単 分子膜の層内および層間相互作用が絨維状形態形成にとって重要な因子であることを見いだした。 HARM 構造 は生体系繊維構造と同様に階層的に構築される。

（連絡者：清水敏美） Vol.49, No.10，1261（2000）

\section{[総説］デンドリマー－金属ナノコンポジットの} 合成とその物性

\author{
鳥越 幹二郎 - 江角邦男 \\ 東京理科大学理学部応用化学科- 界面科学研究所 \\ （テ162-8601 東京都新宿区神楽坂 1-3）
}

1980 年代半ば以来, 多分岐高分子であるデンドリマーに幅広い関心が寄せられている。さまざまな金属ナノ 粒子とデンドリマーのナノコンポジットが調製され, 基質選択性触媒, 化学センサーなどの高機能性材料への応 用に関する研究も行われている。本稿では，代表的なポリアミドアミンデンドリマーを中心にデンドリマーー金 属ナノ粒子コンポジットの合成とその物性について解説する。

（連絡者：鳥越幹二郎） Vol.49, No.10, 1271 (2000) 